\title{
Phase Evolution, Microstructure and Microwave Dielectric Properties of $\mathrm{Zn}_{1.9-2 \mathrm{x}} \mathrm{Li}_{\mathrm{x}} \mathrm{Al}_{\mathrm{x}} \mathrm{Si}_{1.05} \mathrm{O}_{4}$ Ceramics
}

\author{
Yun-Han Kim, Shin Kim*, Seong-Min Jeong**, So-Jung Kim****, and Sang-Ok Yoon ${ }^{\dagger}$ \\ Department of Materials Engineering, Graduate School, Gangneung-Wonju National University, Gangneung 210-702, Korea \\ *Hasla Co., Ltd, Gangneung 210-340, Korea \\ **Energy \& Environmental Division, Korea Institute of Ceramic Engineering and Technology(KICET), Seoul 153-801, Korea \\ ***Department of Electrical and Electronic Engineering, Hanzhong University, Donghae 240-713, Korea
}

(Received March 13, 2015; Revised May 4, 2015; Accepted May 6, 2015)

\begin{abstract}
Phase evolution, microstructure, and microwave dielectric properties of $\mathrm{Li}_{2} \mathrm{O}$ and $\mathrm{Al}_{2} \mathrm{O}_{3}$ doped $\mathrm{Zn}_{19} \mathrm{Si}_{105} \mathrm{O}_{4}$, i.e., $\mathrm{Zn}_{19.2 \mathrm{x}} \mathrm{Li}_{\mathrm{x}} \mathrm{Al}$ $\mathrm{Si}_{1.05} \mathrm{O}_{4}$, ceramics $(\mathrm{x}=0.02 \sim 0.10)$ were investigated. The ceramics were densified by $\mathrm{SiO}_{2}$-rich liquid phase composed of the Li-Al$\mathrm{Si}-\mathrm{O}$ system, indicating that doped $\mathrm{Li}$ and $\mathrm{Al}$ contributed to the formation of the liquid. As the secondary phase, $\beta$-spodumene solid solution with the composition of $\mathrm{LiAlSi}_{3} \mathrm{O}_{8}$ was precipitated from the liquid during the cooling process. The dense ceramics were obtained for the specimens of $\mathrm{x} \geqq 0.06$ showing the rapid densification above $1000^{\circ} \mathrm{C}$, implying that a certain amount of liquid is necessary to densify. The specimen of $\mathrm{x}=0.06$ sintered at $1050^{\circ} \mathrm{C}$ exhibited good microwave dielectric properties; the dielectric constant and the quality factor $\left(\mathrm{Q} \times \mathrm{f}_{0}\right)$ were 6.4 and $11,213 \mathrm{GHz}$, respectively.
\end{abstract}

Key words : $\mathrm{Zn}_{2} \mathrm{SiO}_{p}$ Liquid-phase sintering, LiAlSi ${ }_{3} \mathrm{O}_{8}$, Dielectric constant, Quality factor

\section{Introduction}

A $\mathrm{s}$ a result of drastic recent development of wireless communication industry, studies and development of microwave dielectric ceramics used for mobile phones, wireless LAN (Local Area Network), GPS (Global Position Satellite), military radar system, Intelligent Transport System (ITS), etc. are being actively conducted. ${ }^{1-3)}$ Dielectric properties of microwave dielectric ceramics are specified by dielectric constant $\left(\varepsilon_{\mathrm{r}}\right)$, quality factor(Q), temperature coefficient of resonance frequency $\left(\tau_{f}\right)$, while the quality factor, i.e., the inverse of dielectric loss, is varied with frequency so as to be generally expressed as a product with resonance frequency $\left(\mathrm{f}_{0}\right)$, i.e., $\left(\mathrm{Q} \times \mathrm{f}_{0}\right)$. ${ }^{3)}$

For substrate materials applied to Microwave Integrated Circuit (MIC) among dielectric ceramics employed in the microwave domain, a low dielectric constant, a high quality factor (low dielectric loss) and a temperature coefficient of resonance frequency approaching 0 are required. ${ }^{4)}$ As the ceramics showing a low dielectric constant and a high quality factor, $\mathrm{Al}_{2} \mathrm{O}_{3}, \mathrm{Mg}_{2} \mathrm{SiO}_{4}$ (fosterite), $\mathrm{Zn}_{2} \mathrm{SiO}_{4}$ (willemite), etc. have been reported ${ }^{2-4)}$ Guo et al. stated that dielectric constant and quality factor of $\mathrm{Zn}_{2} \mathrm{SiO}_{4}$ synthesized by a solid phase reaction method and sintered at $1340^{\circ} \mathrm{C}$ were 6.6 and $219,000 \mathrm{GHz}$, respectively, while a specimen with doping of $\mathrm{TiO}_{2}$ showed a temperature coefficient of resonance fre-

${ }^{\dagger}$ Corresponding author : Sang-Ok Yoon

E-mail : soyoon@gwnu.ac.kr

Tel : +82-33-640-2361 Fax : +82-33-640-2244 quency close to 0 although its dielectric constant was increased to 9.3, and the quality factor decreased to 113,000 GHz. ${ }^{4)}$ Dong et al. also reported that $\mathrm{Zn}_{2} \mathrm{SiO}_{2}-\mathrm{TiO}_{2}$ ceramics prepared by sol-gel method exhibited similar dielectric properties and its application to a millimeter wave domain was possible. ${ }^{5)}$

In the meanwhile, studies are being reported where sintering temperature may be lowered by adding sintering aids such as $\mathrm{Li}_{2} \mathrm{CO}_{3}, \mathrm{Li}_{2} \mathrm{CO}_{3}+\mathrm{Bi}_{2} \mathrm{O}_{3}, \mathrm{Bi}_{2} \mathrm{O}_{3}, \mathrm{~V}_{2} \mathrm{O}_{5}, \mathrm{~B}_{2} \mathrm{O}_{3}, \mathrm{BaO}+\mathrm{B}_{2} \mathrm{O}_{3}$, glasses based on $\mathrm{ZnO}-\mathrm{B}_{2} \mathrm{O}_{3}-\mathrm{SiO}_{2}$, etc. to enable co-firing of $\mathrm{Zn}_{2} \mathrm{SiO}_{4}$ with metal electrodes. ${ }^{6-13)} \mathrm{Kim}$ et al. have reported a study where sintering temperature of $\mathrm{Zn}_{1.8} \mathrm{SiO}_{3.8}$ was lowered to $900^{\circ} \mathrm{C}$ in a composition with doping of $25.0 \mathrm{~mol} \%$ $\mathrm{B}_{2} \mathrm{O}_{3}$ while maintaining excellent microwave dielectric properties. ${ }^{11)}$ However, Li et al. have reported in a study on water-system tape casting that viscosities of slurry were drastically increased with contents of $\mathrm{B}_{2} \mathrm{O}_{3}$ doped to lower sintering temperature of the ceramics based on $\mathrm{Li}_{2} \mathrm{O}-\mathrm{Nb}_{2} \mathrm{O}_{5}$ $\mathrm{TiO}_{2}$, which was attributed to the fact that $\mathrm{B}(\mathrm{OH})_{4}{ }^{-}$was produced by dissolution of $\mathrm{B}_{2} \mathrm{O}_{3}$ in the aqueous solution. ${ }^{14)}$ Also, tensile strength and density of the tape were decreased with an increase in the doped amounts of $\mathrm{B}_{2} \mathrm{O}_{3}$, which was attributed to a decrease in dispersibility of particles and an increase in viscosity of the slurry due to the doped $\mathrm{B}_{2} \mathrm{O}_{3}$. Therefore, attention needs to be paid when moisture or water is included in a manufacturing process, although doping of $\mathrm{B}_{2} \mathrm{O}_{3}$ allows a reduction in sintering temperature for $\mathrm{Zn}_{2} \mathrm{SiO}_{4}$.

In the meanwhile, Nguyen et al. have reported results where grain growth due to evolution of a liquid phase in a 
composition of $\mathrm{Zn}_{2} \mathrm{SiO}_{4}$ with insufficient $\mathrm{Zn}$, i.e., $\mathrm{Zn}_{1.8} \mathrm{SiO}_{3.8}$ along with excellent microwave dielectric properties were manifested. ${ }^{15)}$ Also, Kim has reported in a study on $\mathrm{Zn}_{2}$. ${ }_{2 \mathrm{y}} \mathrm{Si}_{1+\mathrm{y}} \mathrm{O}_{4}$ system that $\mathrm{Zn}_{1.9} \mathrm{Si}_{1.05} \mathrm{O}_{4}$ composition showed the most excellent microwave dielectric properties. ${ }^{16)}$ In the present study, phase evolution, microstructure, sintering behavior and microwave dielectric properties of $\mathrm{Zn}_{1.9-2 \mathrm{x}} \mathrm{Li}_{\mathrm{x}}$ $\mathrm{Al}_{\mathrm{x}} \mathrm{Si}_{1.05} \mathrm{O}_{4}$ with doping of $\mathrm{Li}_{2} \mathrm{O}$ and $\mathrm{Al}_{2} \mathrm{O}_{3}$ to $\mathrm{Zn}_{1.9} \mathrm{Si}_{1.05} \mathrm{O}_{4}$. have been evaluated and the results been discussed.

\section{Experimental Procedure}

In the present study, powders of $\mathrm{ZnO}$ (99.9\% in purity), $\mathrm{SiO}_{2}\left(99.9 \%\right.$ in purity), $\mathrm{Li}_{2} \mathrm{CO}_{3}$ (99.9\% in purity), $\mathrm{Al}_{2} \mathrm{O}_{3}$ (99.9\% in purity) produced by Kojundo Chem. Lab. Co., Ltd. of Japan have been used as a starting raw material. Powders of $\mathrm{Zn}_{1.9-2 \mathrm{x}} \mathrm{Li}_{\mathrm{x}} \mathrm{Al}_{\mathrm{x}} \mathrm{Si}_{1.05} \mathrm{O}_{4}$ corresponding to $\mathrm{x}=0.02,0.04$, $0.06,0.08,0.10$, zirconia balls and ethyl alcohol were placed in a polyethylene container to be ball-milled for $24 \mathrm{~h}$. Mixed powders were calcined after drying, under the calcination conditions of $900^{\circ} \mathrm{C}$ for $10 \mathrm{~h}$. No grain growth was observed in the calcined powders. Calcined powders ground by dry method were placed in a metallic mold of $15 \mathrm{~mm}$ in diameter for uniaxial pressure-forming under a pressure of $50 \mathrm{MPa}$. A green body was then sintered at $1000 \sim 1200^{\circ} \mathrm{C}$ for $2 \mathrm{~h}$. The heating rate was $10^{\circ} \mathrm{C} / \mathrm{min}$, followed by natural cooling.

Bulk density was measured by Archimedes method, and X-ray diffraction analysis (D/MAX-2500V/PC, Rigaku, Japan) was conducted for powders obtained by grinding a specimen. Also, surfaces of a specimen were polished, and microstructures observed with S-4200 (Hitachi, Japan) at a lower temperature than the sintering temperature by $50 \sim 100^{\circ} \mathrm{C}$ for $10 \sim 30$ minutes. Microwave dielectric properties were measured by Hakki-Coleman method using a network analyzer (HP8720ES, Agilent, U.S.A.).

\section{Results and Discussion}

Powder X-ray diffraction patterns of $\mathrm{Zn}_{1.9-2 \mathrm{x}} \mathrm{Li}_{\mathrm{X}} \mathrm{Al}_{\mathrm{x}} \mathrm{Si}_{1.05} \mathrm{O}_{4}$ $(\mathrm{x}=0.02 \sim 0.10)$ which was sintered at $1050^{\circ} \mathrm{C}$ for $2 \mathrm{~h}$ is shown in Fig. 1. Diffraction peaks of all compositions excluding a minor amount of secondary phase were in agreement with diffraction patterns of rhombohedral $\mathrm{Zn}_{2}$. $\mathrm{SiO}_{4}$ (ICDD (International Centre for Diffraction Data) File 70-1235). Diffraction peaks of $\mathrm{ZnO}$ or $\mathrm{SiO}_{2}$ reported to be produced as the secondary phases in calcined powders or sintered specimens of $\mathrm{Zn}_{2} \mathrm{SiO}_{4}$ were not observed. ${ }^{13,15)}$ While diffraction peaks of the secondary phase were not observed in the composition of $\mathrm{x}=0.02$ (Fig. 1(a)), these ( $\mathbf{\nabla}$ ) were observed in the compositions above $\mathrm{x}=0.04$ (Figs. 1(b) $\sim(\mathrm{e})$ ) where diffraction intensities of the secondary phase were increased with an increase in $\mathrm{x}$ values, i.e., the contents of $\mathrm{Li}_{2} \mathrm{O}$ and $\mathrm{Al}_{2} \mathrm{O}_{3}$. This result suggests that the produced secondary phase is a compound including $\mathrm{Li}_{2} \mathrm{O}$ and $\mathrm{Al}_{2} \mathrm{O}_{3}$. While intensities of diffraction peaks for the secondary phase are relatively low and there exist peaks overlapping with the diffraction peaks of $\mathrm{Zn}_{2} \mathrm{SiO}_{4}$, the second phase has very similar diffraction peaks to those of lithium orthoclase

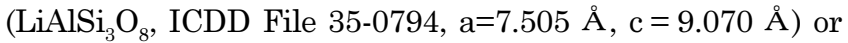
$\beta$-spodumene $\left(\beta-\mathrm{LiAlSi}_{2} \mathrm{O}_{6}\right.$, ICDD File 35-0797, $\mathrm{a}=7.539 \AA$, $c=9.148 \AA$ ) of orthorhombic structure in the ternary component system of $\mathrm{Li}_{2} \mathrm{O}-\mathrm{Al}_{2} \mathrm{O}_{3}-\mathrm{SiO}_{2}$. Included in the pseudo binary system of $\mathrm{Li}_{2} \mathrm{O} \cdot \mathrm{Al}_{2} \mathrm{O}_{3}-\mathrm{nSiO}_{2}$ among the above ternary system are $\beta$-eucryptite $\left(\mathrm{n}=2, \beta\right.$-LiAlSiO $\left.{ }_{4}\right), \beta$-spodumene $\left(\mathrm{n}=4, \beta-\mathrm{LiAlSi}_{2} \mathrm{O}_{6}\right)$, lithium orthoclase $\left(\mathrm{n}=6, \mathrm{LiAlSi}_{3} \mathrm{O}_{8}\right)$ and petalite $\left(\mathrm{n}=8, \mathrm{LiAlSi}_{4} \mathrm{O}_{10}\right),{ }^{17,18)}$ where $\mathrm{LiAlSi}_{3} \mathrm{O}_{8}$ is reported as the solid solution of $\beta$ - $\mathrm{LiAlSi}_{2} \mathrm{O}_{6}{ }^{19,20)}$ Based on the result where diffraction peaks of the second phase were observed at higher angles than the diffraction peaks of $\beta$ $\mathrm{LiAlSi}_{2} \mathrm{O}_{6}$, the second phase is considered to be close to LiAl$\mathrm{Si}_{3} \mathrm{O}_{8}$ having smaller lattice constants than $\beta$-LiAlSi ${ }_{2} \mathrm{O}_{6}$. In Fig. 2, intensity ratio for the diffraction peaks at $2 \theta \approx 27.3^{\circ}$ and $28.3^{\circ}\left(\mathrm{I}_{28.3^{3}} / \mathrm{I}_{27.3^{\circ}}\right)$ obtained as a Gaussian function is shown as a function of $\mathrm{x}$ values, Diffraction peaks at $2 \theta \approx 27.3^{\circ}$ and $28.3^{\circ}$ correspond to $(21 \overline{2})$ and $(31 \overline{1})$ diffraction planes of $\mathrm{Zn}_{2} \mathrm{SiO}_{4}$, respectively. As $\mathrm{x}$ values were increased, the resulting increase in intensity ratios was indicated, which appears to be due to the fact that (211) diffraction peak of $\mathrm{LiAlSi}_{3} \mathrm{O}_{8}$ in the neighborhood of $28.3^{\circ}$ is

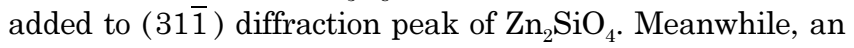

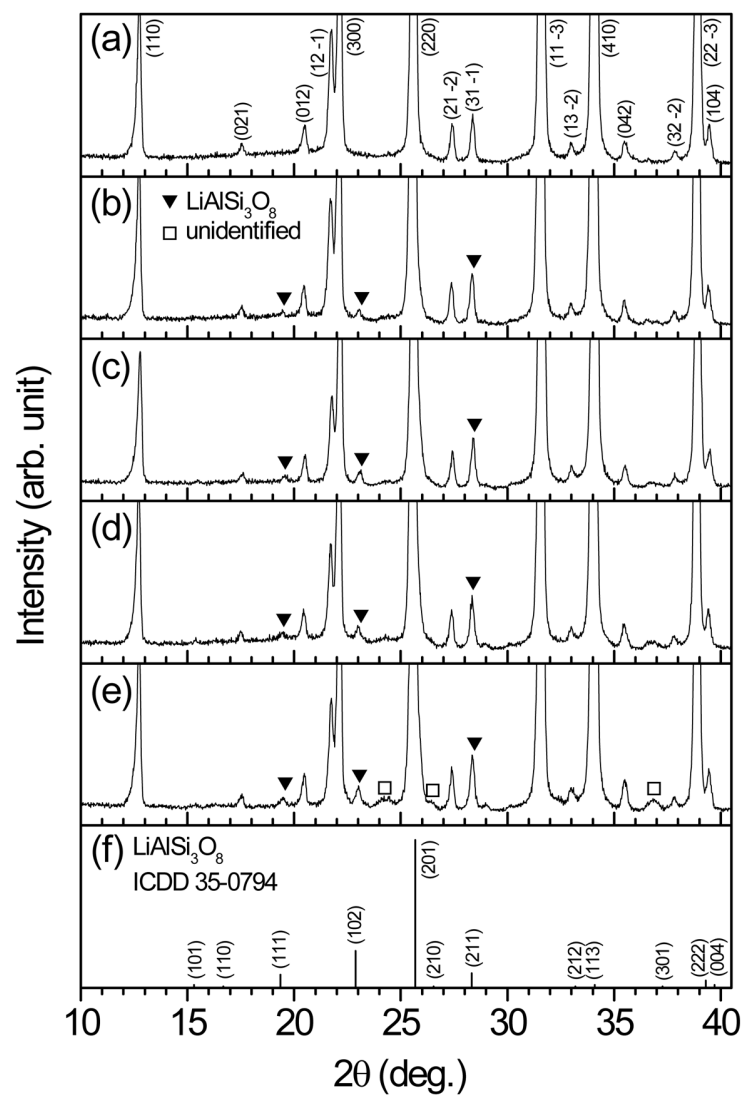

Fig. 1. Powder $\mathrm{X}$-ray diffraction patterns of $\mathrm{Zn}_{1.9-2 \mathrm{x}} \mathrm{Li}_{\mathrm{x}} \mathrm{Al}_{\mathrm{x}}$ $\mathrm{Si}_{1.05} \mathrm{O}_{4}$ sintered at $1050^{\circ} \mathrm{C}$ for $2 \mathrm{~h}$; (a) $\mathrm{x}=0.02$, (b) 0.04 , (c) 0.06 , (d) 0.08 , (e) 0.10 , and (f) $\mathrm{LiAlSi}_{3} \mathrm{O}_{8}$ (ICDD File 35-0794). 


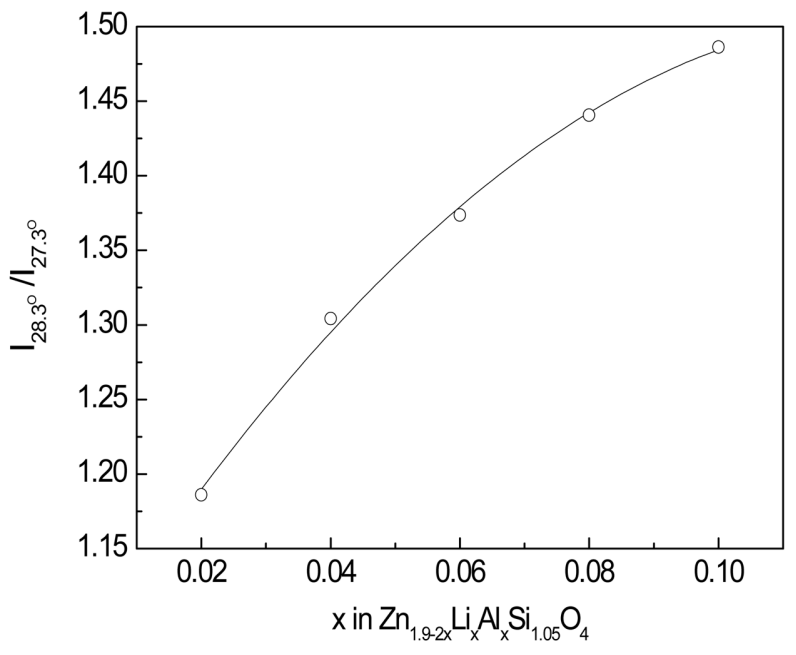

Fig. 2. Intensity ratio of X-ray diffraction peaks for $2 \theta \approx$ $28.3^{\circ}$ and $27.3^{\circ}$ as a function of $\mathrm{x}$ in $\mathrm{Zn}_{1.9-2 \mathrm{x}} \mathrm{Li}_{x} \mathrm{Al}_{\mathrm{x}} \mathrm{Si}_{1.05} \mathrm{O}_{4}$.

unidentified diffraction peak ( $\square$ )was also observed, for which additional studies are needed.

Bulk density as a function of sintering temperature are given in Fig. 3, showing different results depending on $\mathrm{x}$ values. Namely, whereas bulk density of $\mathrm{x}=0.02$ and 0.04 compositions are gradually increased up to $1200^{\circ} \mathrm{C}$, bulk density of compositions above $\mathrm{x}=0.06$ are rapidly increased after $1000^{\circ} \mathrm{C}$, leading to completion of densification at $1050^{\circ} \mathrm{C}$. Sintering mechanism of $\mathrm{Zn}_{2} \mathrm{SiO}_{4}$ is known to be liquid-phase sintering, and sintering aids such as $\mathrm{Li}_{2} \mathrm{CO}_{3}, \mathrm{Li}_{2}$. $\mathrm{CO}_{3}+\mathrm{Bi}_{2} \mathrm{O}_{3}, \mathrm{Bi}_{2} \mathrm{O}_{3}, \mathrm{~V}_{2} \mathrm{O}_{5}, \mathrm{~B}_{2} \mathrm{O}_{3}, \mathrm{BaO}+\mathrm{B}_{2} \mathrm{O}_{3}$, glasses based on $\mathrm{ZnO}-\mathrm{B}_{2} \mathrm{O}_{3}-\mathrm{SiO}_{2}$ are reported to produce a liquid phase for contribution to densification of $\mathrm{Zn}_{2} \mathrm{SiO}_{4}$ as mentioned in the introduction. ${ }^{6-13)}$ Meanwhile, in the pseudo ternary system of $\mathrm{SiO}_{2}-\mathrm{Li}_{2} \mathrm{SiO}_{3}-\mathrm{LiAlSi}_{2} \mathrm{O}_{6}$, eutectic points exist at $975^{\circ} \mathrm{C}$ and $980^{\circ} \mathrm{C}$, which correspond to a $\mathrm{SiO}_{2}$-rich domain in the ternary system of $\mathrm{SiO}_{2}-\mathrm{Li}_{2} \mathrm{O}-\mathrm{Al}_{2} \mathrm{O}_{3} \cdot{ }^{21)}$ Hence, in the present system, compositions near the above eutectic points are considered to form a liquid phase above $975^{\circ} \mathrm{C} \sim 980^{\circ} \mathrm{C}$ for contribution to densification and for precipitation as LiAl$\mathrm{Si}_{3} \mathrm{O}_{8}$ in the cooling process. This suggestion is substantiated by the result where bulk density for the compositions above $x=0.06$ are drastically increased above $1000^{\circ} \mathrm{C}$. Also, based on the fact that bulk density show different results

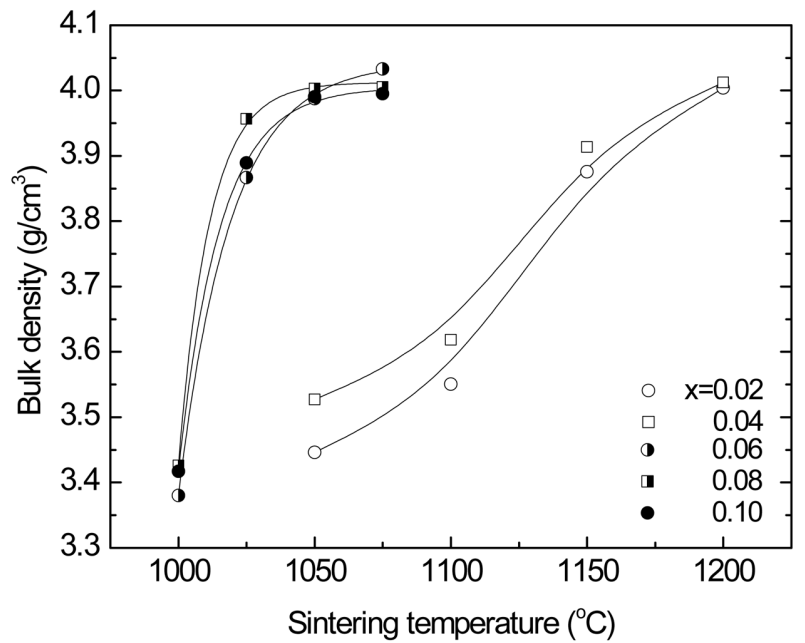

Fig. 3. Bulk density of $\mathrm{Zn}_{1.9-2 \mathrm{x}} \mathrm{Li}_{\mathrm{x}} \mathrm{Al}_{\mathrm{x}} \mathrm{Si}_{1.05} \mathrm{O}_{4}$ as a function of sintering temperature.

depending on $\mathrm{x}$ values, it is presumed that the amount of liquid phase should be more than a given amount for effective densification. To obtain a dense $\mathrm{Zn}_{2} \mathrm{SiO}_{4}$, sintering at high temperatures above $1350^{\circ} \mathrm{C}$ is reported to be required, and it may be seen that a dense specimen can be obtained at about $1000^{\circ} \mathrm{C}$ by doping of $\mathrm{Li}_{2} \mathrm{O}$ and $\mathrm{Al}_{2} \mathrm{O}_{3}$. Meanwhile, $\mathrm{Mn}$ substituted $\mathrm{Zn}_{2} \mathrm{SiO}_{4}$ is widely applied as a fluorescent substance, where Mn has been reported to be substituted in $\mathrm{Zn}^{2+}$ sites, ${ }^{22)}$ and luminous colors from purple color to infrared radiation are exhibited, which is due to the fact that doping of diversified ions is possible. The only stable phase of $\mathrm{Zn}_{2} \mathrm{SiO}_{4}$ in the binary system of $\mathrm{ZnO}-\mathrm{SiO}_{2}$ under atmospheric pressure shows a phenacite structure (space group: $\mathrm{R} \overline{3}$ ) with the coordination number for both $\mathrm{Zn}^{2+}$ and $\mathrm{Si}^{4+}$ ions being $4 .^{23)}$ However, based on the results of the present study, the doped $\mathrm{Li}^{+}$and $\mathrm{Al}^{3+}$ ions are considered to contribute to evolution of a liquid phase rather than being substituted in $\mathrm{Zn}^{2+}$ sites. Ionic radius of $\mathrm{Zn}^{2+}$ in the case of the coordination number of 4 is $0.6 \AA$, and that of $\mathrm{Li}^{+}$is similar at $0.59 \AA$, while that of $\mathrm{Al}^{3+}$ is smaller at $0.39 \AA .^{24)}$ Therefore, substitution is considered not to have been easily realized due to size differences between $\mathrm{Al}^{3+}$ ions and $\mathrm{Zn}^{2+}$ ions.

Shown in Fig. 4(a), (b), and (c) are microstructures for the compositions of $\mathrm{x}=0.02,0.06$ and 0.10 , respectively. Sinter-
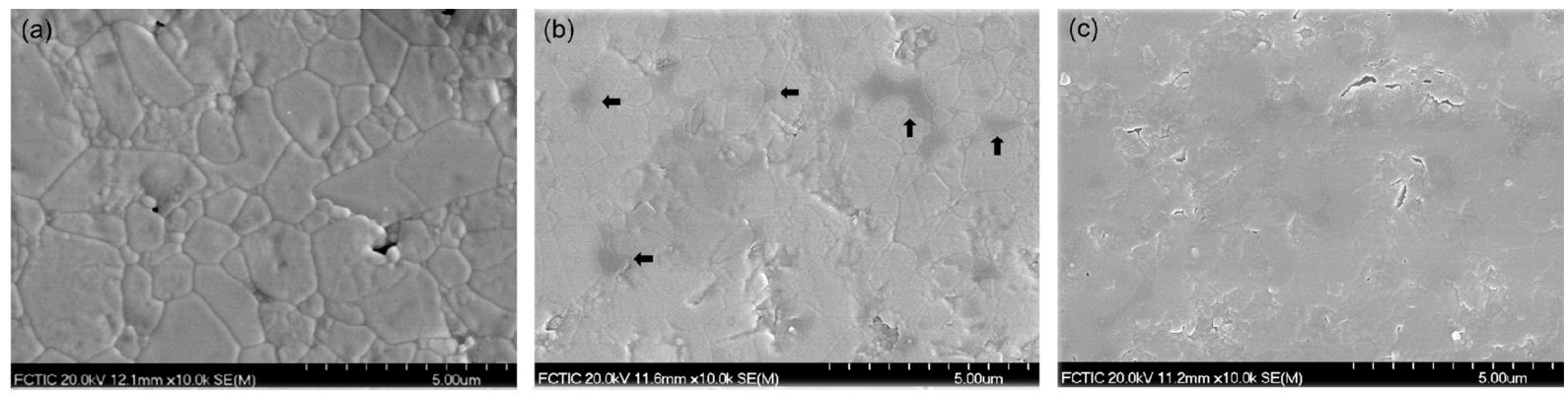

Fig. 4. FE-SEM photographs of $\mathrm{Zn}_{19-2 \mathrm{x}} \mathrm{Li}_{\mathrm{x}} \mathrm{Al}_{\mathrm{x}} \mathrm{Si}_{105} \mathrm{O}_{4}$; (a) $\mathrm{x}=0.02$, (b) 0.06 , and (c) $\mathrm{x}=0.10 . \mathrm{X}=0.02$ was sintered at $1200^{\circ} \mathrm{C}$ for $2 \mathrm{~h}$ whereas $\mathrm{x}=0.06$ and 0.10 were sintered at $1050^{\circ} \mathrm{C}$ for $2 \mathrm{~h}$. 
ing temperature for the composition of $\mathrm{x}=0.02$ was $1200^{\circ} \mathrm{C}$, while that for the compositions of $x=0.06$ and 0.10 was $1050^{\circ} \mathrm{C}$. Excluding some pores observed for the composition of $\mathrm{x}=0.10$, a dense microstructure was observed for all compositions. Grains shown by an arrow in the composition of $\mathrm{x}=0.06$ are shown to be relatively dark, which imply their being composed of light elements. Therefore, these grains are considered to be $\mathrm{LiAlSi}_{3} \mathrm{O}_{8}$ rather than $\mathrm{Zn}_{2} \mathrm{SiO}_{4}$, and to exist as a liquid phase at a sintering temperature of $1050^{\circ} \mathrm{C}$ contributing to densification, followed by crystallization during cooling as mentioned earlier. In the composition of $\mathrm{x}=0.02$, it is difficult to observe $\mathrm{LiAlSi}_{3} \mathrm{O}_{8}$ grains, which is in agreement with the X-ray diffraction analysis result where no second phases were observed as shown in Fig. 1(a). However, based on the results where grains grown to more than $2 \sim 3 \mu \mathrm{m}$ were also observed for this composition and flat grain boundaries existed, densification appears to have been realized by liquid-phase sintering as in the composition of $\mathrm{x}=0.06$. German et al. stated that liquid-phase sintering occurred when a solid was dissolved in a liquid phase, and solid grains were mutually attracted due to wetting of liquid phase for solid grains and capillary tube forces produced thereby. ${ }^{25,26)}$ It was also stated that contact points of solid-phase grains were subjected to a compressive stress due to capillary force, and dissolution preferentially occurred at contact points as a result, while contact flattening of grains was realized due to matter transport to grain necks and precipitation. Also, the results were observed where grain size for the composition of $\mathrm{x}=0.02$ with a little doping of $\mathrm{Li}_{2} \mathrm{O}$ and $\mathrm{Al}_{2} \mathrm{O}_{3}$ were larger than those for the composition of $\mathrm{x}=0.06$, and such results are considered attributable to the higher sintering temperature. Therefore, because of the relatively low sintering temperature, it is considered to be in dissolution-precipitation process following grain rearrangement one in the compositions above $\mathrm{x}=0.06$. Grain boundaries in the composition of $\mathrm{x}=0.10$ are not clear as compared with the compositions of $x=0.02$ and 0.60 (Fig. $3(\mathrm{c})$ ), which is considered to be caused by excessive evolution of a liquid phase as the result of an increase in the doped amounts of $\mathrm{Li}_{2} \mathrm{O}$ and $\mathrm{Al}_{2} \mathrm{O}_{3}$.

Dielectric constant and quality factor $\left(\mathrm{Q} \times \mathrm{f}_{0}\right)$ as a function of sintering temperature are shown in Figs. 5 and 6, respectively. Dielectric constant showed similar results to the behavior of bulk density, and appear to be greatly affected by density, i.e., porosity. Penn at al. also reported in a study on dielectric properties of alumina ceramics in a microwave domain that porosity had an effect on dielectric constant although impurities or grain size did not have a great effect on the dielectric constant. ${ }^{27)}$ Also, as shown in Fig. 3 and Fig. 5, while bulk density sintered above $1050^{\circ} \mathrm{C}$ are somewhat higher for the compositions of $\mathrm{x}=0.06 \sim 0.08$ than for the composition of $x=0.10$, dielectric constant for the composition of $\mathrm{x}=0.10$ showed a higher value, and this is considered to be related to evolution of $\mathrm{LiAlSi}_{3} \mathrm{O}_{8}$ as the second phase. Dielectric constant (7.7) of $\beta$-spodumene ( $\beta$-LiAl$\mathrm{Si}_{2} \mathrm{O}_{6}$ ) with the same structure as that of $\mathrm{LiAlSi}_{3} \mathrm{O}_{8}$ has been

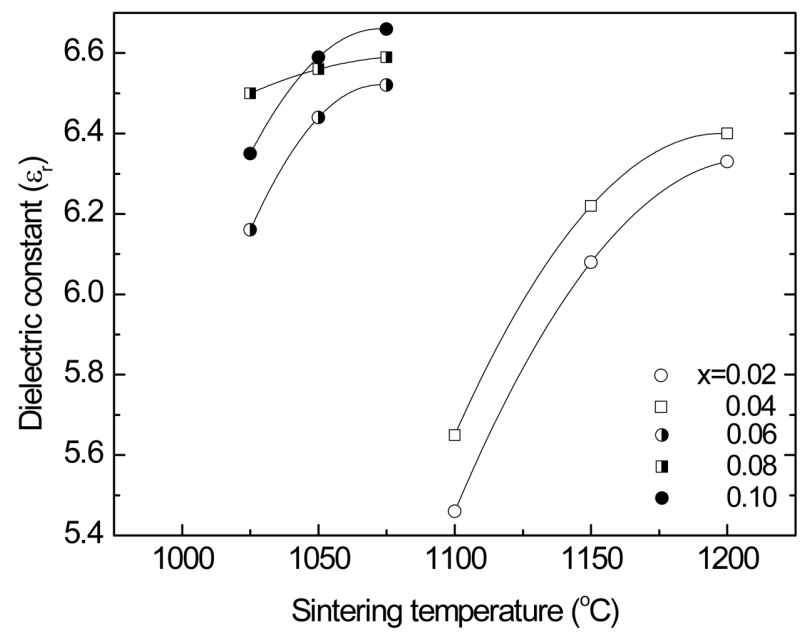

Fig. 5. Dielectric constant of $\mathrm{Zn}_{1.9-2 \mathrm{x}} \mathrm{Li}_{\mathrm{x}} \mathrm{Al}_{\mathrm{x}} \mathrm{Si}_{1.05} \mathrm{O}_{4}$ as a function of sintering temperature.

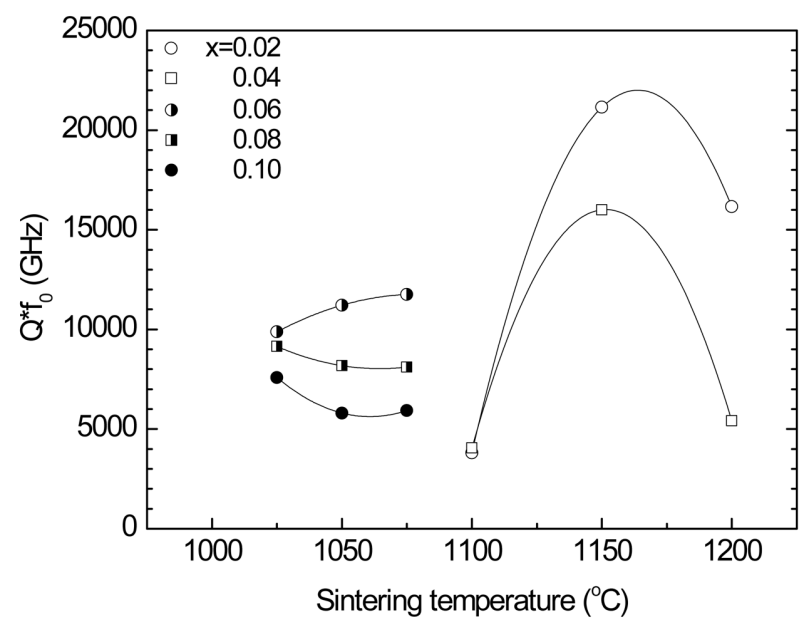

Fig. 6. Quality factor of $\mathrm{Zn}_{1.9-2 \mathrm{x}} \mathrm{Li}_{\mathrm{x}} \mathrm{Al}_{\mathrm{x}} \mathrm{Si}_{1.05} \mathrm{O}_{4}$ as a function of sintering temperature.

reported to be higher than the value of $\mathrm{Zn}_{2} \mathrm{SiO}_{4}{ }^{28)}$ Whereas dielectric constant as a function of sintering temperature showed similar results to the behavior of bulk density, quality factor showed different results. This implies that quality factor is affected by several factors in addition to the effect of porosity (density). In general, reports are also being made that external factors such as impurities, defects, grain boundaries, porosity, microcracks, grain size, electrical conductivity, stress have a greater effect than internal factors caused by phonon interactions. ${ }^{29,30)}$ Quality factor of the compositions of $\mathrm{x}=0.02$ and 0.04 fired at $1100^{\circ} \mathrm{C} \sim 1200^{\circ} \mathrm{C}$ were increased from 3,809 and 4,049 $\mathrm{GHz}$, and showed 21,149 and $16,005 \mathrm{GHz}$, respectively at $1150^{\circ} \mathrm{C}$, after which a tendency of decrease at $1200^{\circ} \mathrm{C}$ was again exhibited. Quality factor of the compositions above $\mathrm{x}=0.06$ fired at $1025^{\circ} \mathrm{C} \sim 1075^{\circ} \mathrm{C}$ showed 5,803 11,755 GHz, and were decreased with an increase in $\mathrm{x}$ values. The decrease in the quality factor is attributed to evolution of the secondary phase, evolution of a liquid phase based on $\mathrm{Li}_{2} \mathrm{O}-\mathrm{Al}_{2} \mathrm{O}_{3}-\mathrm{SiO}_{2}$ of $\mathrm{SiO}_{2}$-rich composition, and an increase in $\mathrm{Zn} / \mathrm{Si}$ of grains 
as a result of evolution of the liquid phase. In a study on microwave properties of $\mathrm{Zn}_{2-2 \mathrm{y}} \mathrm{Si}_{1+\mathrm{y}} \mathrm{O}_{4}$, Kim has reported that quality factor of the composition of $\mathrm{Zn}_{1.9} \mathrm{Si}_{1.05} \mathrm{O}_{4}$ with $\mathrm{Zn} /$ $\mathrm{Si}=1.81$ showed a very high value of $115,166 \mathrm{GHz}$ whereas that of $\mathrm{Zn} / \mathrm{Si}=2$ sintered at $1400^{\circ} \mathrm{C}$, i.e., $\mathrm{Zn}_{2} \mathrm{SiO}_{4}$ with the stoichiometric composition was $51,634 \mathrm{GHz} .{ }^{16)}$ In the future, studies are deemed necessary for improvement of quality factor while maintaining low-temperature sinterability.

\section{Conclusions}

Phase evolution, microstructure, sintering behavior and microwave properties have been studied for $\mathrm{Zn}_{1.9} \mathrm{Si}_{1.05} \mathrm{O}_{4}$ doped with $\mathrm{Li}_{2} \mathrm{O}$ and $\mathrm{Al}_{2} \mathrm{O}_{3}$, i.e., $\mathrm{Zn}_{19-2 x} \mathrm{Li}_{x} \mathrm{Al}_{\mathrm{x}} \mathrm{Si}_{105} \mathrm{O}_{4}(\mathrm{x}=0.02 \sim 0.10)$. While only $\mathrm{Zn}_{2} \mathrm{SiO}_{4}$ was observed as a crystalline phase in the composition of $x=0.02, \operatorname{LiAlSi}_{3} \mathrm{O}_{8}$ as $\beta$-spodumene $(\beta$ $\mathrm{LiAlSi}_{2} \mathrm{O}_{6}$ ) solid solution has been produced as the secondary phase in addition to $\mathrm{Zn}_{2} \mathrm{SiO}_{4}$ in the compositions above $\mathrm{x}=0.04$. Based on the microstructure of specimens, densification by a liquid phase is considered to have occurred. Bulk density as a function of sintering temperature showed different results depending on the compositions. Whereas the compositions of $\mathrm{x}=0.02$ and 0.04 showed a gradual increase in bulk density up to $1200^{\circ} \mathrm{C}$, the compositions above $\mathrm{x}=$ 0.06 showed a drastic increase after $1000^{\circ} \mathrm{C}$ leading to completion of densification at $1050^{\circ} \mathrm{C}$.Based on such results, densification is presumed to occur effectively when a liquid phase exists by more than a given amount. Doped $\mathrm{Li}_{2} \mathrm{O}$ and $\mathrm{Al}_{2} \mathrm{O}_{3}$ are considered to contribute to evolution of a liquid phase based on $\mathrm{Li}_{2} \mathrm{O}-\mathrm{Al}_{2} \mathrm{O}_{3}-\mathrm{SiO}_{2}$ of $\mathrm{SiO}_{2}$-rich composition together with $\mathrm{SiO}_{2}$ rather than being substituted in $\mathrm{Zn}^{2+}$ sites, and to be precipitated as $\mathrm{LiAlSi}_{3} \mathrm{O}_{8}$ in the cooling process.

Dielectric constant in microwave domain as a function of sintering temperature are shown to be greatly affected by porosity. Quality factor showed lower values than those for $\mathrm{Zn}_{1.9} \mathrm{Si}_{1.05} \mathrm{O}_{4}$ sintered at $1350^{\circ} \mathrm{C}$ without doping of $\mathrm{Li}$ and $\mathrm{Al}$. Causes for the low quality factor are attributed to evolution of a liquid phase with $\mathrm{SiO}_{2}$-rich composition, precipitation of $\mathrm{LiAlSi}_{3} \mathrm{O}_{8}$ as the secondary phase, and the corresponding changes in $\mathrm{Zn} / \mathrm{Si}$ of grains. Dielectric constant and quality factor of the composition of $\mathrm{x}=0.06$ fired at $1050^{\circ} \mathrm{C}$ were shown to be 6.4 and $11,213 \mathrm{GHz}$, respectively.

\section{REFERENCES}

1. I. M. Reaney and D. Iddles, "Microwave Dielectric Ceramics for Resonators and Filters in Mobile Phone Networks," J. Am. Ceram. Soc., 89 [7] 2063-72 (2006).

2. H. Ohsato, "Research and Development of Microwave Dielectric Ceramics for Wireless Communications," $J$. Ceram. Soc. Jpn., 113 [11] 703-11 (2005).

3. S. B. Narang and S. Bahel, "Low Loss Dielectric Ceramics for Microwave Applications: A Review," J. Ceram. Process. Res., 11 [3] 316-21 (2010).

4. Y. Guo, H. Ohsato, and K.-I. Kakimoto, "Characterization and Dielectric Behavior of Willemite and $\mathrm{TiO}_{2}$-Doped Wil- lemite Ceramics at Millimeter-Wave Frequency," J. Eur. Ceram. Soc., 26 [10-11] 1827-30 (2006).

5. M. Dong, Z. Yue, H. Zhuang, S. Meng, and L. Li, "Microstructure and Microwave Dielectric Properties of $\mathrm{TiO}_{2}$ Doped $\mathrm{Zn}_{2} \mathrm{SiO}_{4}$ Ceramics Through the Sol-Gel Process," J. Am. Ceram. Soc., 91 [12] 3981-85 (2008).

6. M. Valant, D. Suvorov, R. C. Pullar, K. Sarma, and N. M. Alford, "A Mechanism for Low-Temperature Sintering," J. Eur. Ceram. Soc., 26 [13] 2777-83 (2006).

7. J. L. Zou, Q. L. Zhang, H. Yang, and H. P. Sun, "A New System for Low Temperature Sintering $\mathrm{ZnO}-\mathrm{SiO}_{2}$ Dielectric Ceramics," Jpn. J. Appl. Phys., 45 [5A] 4143-45 (2006).

8. J. S. Kim, N. H. Nguyen, J. B. Lim, D. S. Paik, S. Nahm, J. H. Paik, J. H. Kim, and H.-J. Lee, "Low-Temperature Sintering and Microwave Dielectric Properties of the $\mathrm{Zn}_{2} \mathrm{SiO}_{4}$ Ceramics," J. Am. Ceram. Soc., 91 [2] 671-74 (2008).

9. J. S. Kim, M. E. Song, M. R. Joung, J. H. Choi, S. Nahm, J. H. Paik, B. H. Choi, and H. J. Lee, "Low-Temperature Sintering and Microwave Dielectric Properties of $\mathrm{V}_{2} \mathrm{O}_{5}$-Added $\mathrm{Zn}_{2} \mathrm{SiO}_{4}$ Ceramics," J. Am. Ceram. Soc., 91 [12] 4133-36 (2008).

10. J. S. Kim, N. H. Nguyen, M. E. Song, J. B. Lim, D. S. Paik, S. Nahm, J. H. Paik, B. H. Choi, and S. J. Yu, "Effect of $\mathrm{Bi}_{2} \mathrm{O}_{3}$ Addition on the Sintering Temperature and Microwave Dielectric Properties of $\mathrm{Zn}_{2} \mathrm{SiO}_{4}$ Ceramics," Int. J. Appl. Ceram. Technol., 6 [5] 581-86 (2009).

11. J. S. Kim, M. E. Song, M. R. Joung, J. H. Choi, S. Nahm, S. I. Gu, J. H. Paik, and B. H. Choi, "Effect of $\mathrm{B}_{2} \mathrm{O}_{3}$ Addition on the Sintering Temperature and Microwave Dielectric Properties of $\mathrm{Zn}_{2} \mathrm{SiO}_{4}$ Ceramics," J. Eur. Ceram. Soc., 30 [2] 375-79 (2010).

12. S. Chen, S. Zhang, X. Zhou, X. Lv, and Y. Li, "Low Temperature Preparation of the $\mathrm{Zn}_{2} \mathrm{SiO}_{4}$ Ceramics with the Addition of $\mathrm{BaO}$ and $\mathrm{B}_{2} \mathrm{O}_{3}$," J. Mater. Sci.-Mater. El., 22 [9] 1274-81 (2011)

13. K. Tang, Q. Wu, and X. Xiang, "Low Temperature Sintering and Microwave Dielectric Properties of Zinc Silicate Ceramics," J. Mater. Sci.-Mater. El., 23 [5] 1099-102 (2012).

14. S. Li, Q. Zhang, and H. Yang, "Effect of $\mathrm{B}_{2} \mathrm{O}_{3}$ on the Aqueous Tape Casting and Microwave Properties of $\mathrm{Li}_{2} \mathrm{O}-\mathrm{Nb}_{2} \mathrm{O}_{5}$. $\mathrm{TiO}_{2}$ Ceramics," Prog. Nat. Sci., 23 [2] 152-56 (2013).

15. N. H. Nguyen, J. B. Lim, S. Nahm, J. H. Paik, and J. H. Kim, "Effect of $\mathrm{Zn} / \mathrm{Si}$ Ratio on the Microstructural and Microwave Dielectric Properties of $\mathrm{Zn}_{2} \mathrm{SiO}_{4}$ Ceramics," J. Am. Ceram. Soc., 90 [10] 3127-30 (2007).

16. Y. H. Kim, Microwave Dielectric Properties of $\mathrm{Zn}_{2} \mathrm{SiO}_{4}$ Ceramic Solid Solutions (in Korean), pp. 47-60, in Master Thesis, Gangneung-Wonju National University, Gangneung, 2010.

17. F. Doreau, H. Maupas, D. Kervadec, P. Ruterana, J. Vicens, and J. L. Chermant, "The Complexity of the Matrix Micro Structure in SiC-Fiber-Reinforced Glass Ceramic Composites," J. Eur. Ceram. Soc., 15 [12] 1235-47 (1995).

18. S. Mandal, S. Chakrabarti, S. K. Das, and S. Ghatak, "Synthesis of Low Expansion Ceramics in Lithia-Alumina-Silica System with Zirconia Additive Using the Powder Precursor in the Form of Hydroxyhydrogel," Ceram. Int., 33 [2] 123-32 (2007).

19. D. U. Tulyaganov, S. Agathopoulos, H. R. Fernandes, and 
J. M. F. Ferreira, "Synthesis of Lithium Aluminosilicate Glass and Glass-Ceramics from Spodumene Material," Ceram. Int., 30 [6] 1023-30 (2004).

20. T. Yang and $\mathrm{S}$. Liu, " $\mathrm{Li}_{2} \mathrm{O}-\mathrm{Al}_{2} \mathrm{O}_{3}-\mathrm{SiO}_{2}$ Glass-Ceramic Coating on a Porous Silica Ceramic Substrate," J. Alloy Compd., 600 51-54 (2014).

21. R. Roy and E. F. Osborn, "The System Lithium Metasilicate-Spodumene-Silica," J. Am. Chem. Soc., 71 [6] 2086-95 (1949).

22. S. R. Lukic, D. M. Petrovic, M. D. Dramicanin, M. Mitric, and $\mathrm{Lj}$. Dacanin, "Optical and Structural Properties of $\mathrm{Zn}_{2}$ $\mathrm{SiO}_{4}: \mathrm{Mn}^{2+}$ Green Phosphor Nanoparticles Obtained by a Polymer-Assisted Sol-Gel Method," Scripta Mater., 58 [8] 655-58 (2008).

23. M. Takesue, H. Hayashi, and R. L. Smith Jr., "Thermal and Chemical Methods for Producing Zinc Silicate (Willemite): A Review,” Prog. Cryst. Growth Ch., 55 [3-4] 98-124 (2009).

24. R. D. Shanon, "Revised Effective Ionic Radii and System- atic Studies of Interatomic Distances in Halides and Chalcogenides," Acta Crystallogr A., 32 751-67 (1976).

25. R. M. German, Liquid Phase Sintering, pp. 101-26, Plenum Press, New York, 1985.

26. R. M. German, P. Suri, and S. J. Park, "Review: Liquid Phase Sintering," J. Mater. Sci., 44 [1] 1-39 (2009).

27. S. J. Penn, N. M. Alford, A. Templeton, X. Wang, M. Xu, M. Reece, and K. Schrapel, "Effect of Porosity and Grain Size on the Microwave Dielectric Properties of Sintered Alumina," J. Am. Ceram. Soc., 80 [7] 1885-88 (1997).

28. T. Ogiwara, Y. Noda, K. Shoji, and O. Kimura "Low Temperature Sintering of $\beta$-spodumene Ceramics with Low Thermal Expansion Using $\mathrm{Li}_{2} \mathrm{O}-\mathrm{Bi}_{2} \mathrm{O}_{3}$ as a Sintering additive," J. Ceram. Soc. Jpn., 119 [7] 557-62 (2011).

29. V. L. Gurevich and A. K. Tagantsev, "Intrinsic Dielectric Loss in Crystals," Adv. Phys., 40 [6] 719-67 (1991).

30. N. M. Alford and S. J. Penn, "Sintered Alumina with Low Dielectric Loss,” J. Appl. Phys., 80 [10] 5895-98 (1996). 